\title{
Amnesty International's Response to Canadian Refugee Policy: Evaluations and Recommendations
}

\section{Michael Schelew}

The current evaluation of the Canadian Section of Amnesty International regarding Canadian refugee policy leads us to three basic conclusions:

1) the nature and scale of the refugee question in Canada is seriously misunderstood and badly misrepresented; 2) consequent$1 y$, the response of the Canadian government is inappropriate and excessive in terms of restrictive and deterrent policies; 3) there is a real risk of the abandonment of humanitarian values and commitments established over recent decades and codified in international conventions.

The restrictive nature of current policies prevents access by refugee claimants, notably from Third World States, to Canadian refugee determination procedures. Within this context, the inaccessibility of the appeal procedure means that the proposed determination process is seriously flawed. Of particular concern more recently are the increased uses of detention of refugee claimants.

To an alarming degree, decision-making in the area of refugee policy is moving away from the traditional human rights and humanitarian field of policy-making. It is increasingly the subject in fora which also focus on terrorism, drug trafficking and policing on one hand, and with economic streamlining on the other. Not only are these processes accelerating, but the work of determination itself is taking place increasingly in private with minimal or no consultation with the United Nations High Commission for Refugees (UNHCR) and non-governmental organizations (NGOs).

Public opinion is deeply confused about the issues. Many Canadians have indeed been sensitized to the human rights context of the refugee phenomena by the presence of refugees from many parts of the world in Canada and by public statements of Canadian NGOs, However, many other Canadians manifest racist and xenophobic attitudes which are encouraged by extremist groups and even Members of Parliament in the current government. Regrettably, the federal government has not adequately combatted the racism and xenophobia issues.
The Canadian Section of Amnesty International believes that the following proposals constitute an altemative to the present deteriorating situation. The proposals protect the principle of refugee protection in Canada and respond to the global refugee problem. The proposals cover issues of universal access, orderly resettlement procedures, planned consultative process, extension of protection, and adherence to an international consensus.

An inland refugee determination system must provide universal access to all refugee claimants; an oral hearing on the merits of each claim; and an accessible appeal procedure that can deal with the merits of the claim as well as any legal questions. The UNHCR must be given a meaningful role in this process. All decision-making should be completely independent of immigration and political considerations.

Canada must abandon the imposition of fines on airline companies and the introduction of required travel visas aimed exclusively to prevent people leaving their own country to seek asylum. Such principles are contrary to international legal principles and are probably futile anyway. They distract from the better policy option of planned consultation with countries in the region where an upsurge of violence or atrocity causes unexpected forced migration movements, potentially to Canada.

The UN General Assembly, at its 41 st session in December, 1986, promulgated Resolution 41/70 on International Cooperation to Avert New Flows of Refugees. An international consensus followed the adoption of this resolution. Canada should take the lead in setting into motion the difficult and prolonged action that is required.

Just as Canada needs to harmonize its internal protection and assistance policies, so it needs-also to develop clear policies towards the assistance and protection of refugees outside Canada. Canada has a political interest as well as a humanitarian duty to ensure that all countries with which it has diplomatic, political and economic relations fulfil their basic obligations toward refugees.

Canadian refugee policy depends on the support of public opinion. Thus, the Canadian government should more actively promote a positive image of the refugee. It should encourage training, education and public information work. Canada would find willing partners in the UNHCR and amongst the non-governmental organizations in response to refugees and these critical needs.

Michael Schelew is Spokeperson on Refugee Affairs for the Canadian Section of Amnesty International.

\section{REFUGEE DOCUMENTATION PROJECT}

\section{SEMINAR SERIES}

Dates and topics of forthcoming seminars in the 1988 series, Refugees in Policy and Practice:

$\begin{array}{ll}\text { January 21. } & \begin{array}{l}\text { "Wanted and Unwanted } \\ \text { People on the Move: } \\ \text { Then and Now"; }\end{array} \\ \text { February 11, } & \begin{array}{l}\text { "Refugees - Do they } \\ \text { Cost Too Much? Are } \\ \text { They the 'Right } \\ \text { Kind?"; }\end{array} \\ \text { March 3, } & \begin{array}{l}\text { "Refugee Men, } \\ \text { Refugee Women: } \\ \text { Personal Perspectives"; }\end{array} \\ \text { March 31, } & \begin{array}{l}\text { "Toward a Theory of } \\ \text { Refugees and Forced } \\ \text { Migration." }\end{array}\end{array}$

All seminars will be held between 2-4 p.m. in the Junior Common Room (014), McLaughlin College, York University, Toronto. An open discussion period follows the presentations. Discussants and moderators include academics, practitioners and refugees. For more information telephone: (416) 736-5061. ext. 3639 or 7169 . 